\title{
Prevalence of Allelic Loss at TP53 in Endometrial Carcinomas
}

\author{
Andrzej Semczuk $^{\mathrm{a}}$ Regine Schneider-Stock ${ }^{\mathrm{b}}$ Wiktor Szewczuk $^{\mathrm{a}}$ \\ ${ }^{\text {a } 2 n d ~ D e p a r t m e n t ~ o f ~ G y n e c o l o g y, ~ L u b l i n ~ M e d i c a l ~ U n i v e r s i t y, ~ L u b l i n, ~ P o l a n d ; ~ b ~ D e p a r t m e n t ~ o f ~ P a t h o l o g y, ~}$ \\ Erlangen-Nurnberg University, Erlangen, Germany
}

\section{Key Words}

TP53 - Endometrial carcinoma - Loss of heterozygosity •

Metastasis $\cdot \mathrm{p} 53$

\begin{abstract}
Alterations within the TP53 tumor suppressor belong to the most common genetic features reported in various human neoplasms, including endometrial cancer. In this article, the prevalence of allelic loss at the TP53 locus in primary human endometrial carcinomas (ECs) is discussed. Furthermore, we reviewed the role of allelic imbalance at 17p13.1 in metastatic human ECs on the basis of a literature review and on recently published data ascertained by our laboratory staff.
\end{abstract}

Copyright $\odot 2010$ S. Karger AG, Basel

Alterations within oncogenes, tumor suppressor genes (TSGs), and mismatch-repair genes have been found to play a pivotal role in the development and progression of various human neoplasias [1-3]. TP53, the 'guardian of the genome', is spanned on the short arm of chromosome 17 in region $17 \mathrm{p} 13.1$ and consists of 11 exons. It encodes a $53-\mathrm{kDa}$ phosphoprotein, the activity of which gives rise to a number of intracellular activities, including cell cycle arrest and apoptosis $[4,5]$. TP53 is one of the most frequently mutated genes found in a wide spectrum of sporadically occurring human tumors, including the prima-

\section{KARGER}

Fax +41613061234 E-Mail karger@karger.ch www.karger.com

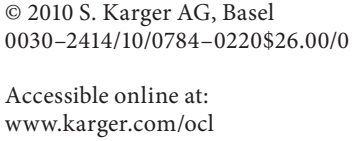

ry origin of endometrial carcinomas (ECs) [6-12]. Mutations of both alleles of TP53, usually caused by a point mutation or gross deletion, and the others by allelic imbalance, constitute an important step in malignant transformation. Furthermore, it has also been reported that tumor tissues obtained from patients with germ line TP53 mutations retain the allele with the germ line mutation and somatically lose the remaining wild-type allele [13]. This phenomenon, explained by the Knutson 'twohit' theory [14], is considered to predispose constitutional TP53 mutation carriers to develop neoplasia. However, it has also been suggested that some germline TP53 mutants may exhibit dominant effects on wild-type p53 function [11]. Moreover, Sakuragi et al. [11] showed that dominant-negative TP53 point mutations are often found in advanced-stage uterine tumors and represent a predictor of unfavorable outcome for women affected by ECs. Therefore, the loss of tumor suppressor functions of wildtype protein caused by these effects of mutant TP53 in germ line is not inconceivable. Possibly, inactivation mutations and allelic loss at TP53 are the most common genetic events in human ECs (particularly in uterine papillary serous carcinoma, UPSC), apart from PTEN alterations and defects in DNA mismatch repair machinery [13, 15-18].

Allelic imbalance is implicated in the development and progression of various human malignancies, and is observed either at an early or advanced stage of neoplasms $[13,19]$. Allelic loss at TP53 locus has been report-
Prof. Andrzej Semczuk

2nd Department of Gynecology, Lublin Medical University

8 Jaczewski Street

PL-20-954 Lublin (Poland)

Tel. +48 81724 4268, Fax +48 81724 4849, E-Mail andrzej.semczuk@am.lublin.pl 
Table 1. Frequency of LOH TP53 in subtype I and II human ECs

\begin{tabular}{|c|c|c|}
\hline \multirow[t]{2}{*}{ Reference } & \multicolumn{2}{|l|}{ Study group } \\
\hline & $\begin{array}{l}\text { cases/subtype II } \\
\text { neoplasms } \\
\text { total } n / n\end{array}$ & $\begin{array}{l}\text { LOH-positive/ } \\
\text { informative } \\
\mathrm{n} / \mathrm{n}\end{array}$ \\
\hline Okamoto et al. [27] & $24 / 0$ & $2 / 7(29 \%)$ \\
\hline Imamura et al. [28] & 42/n.a. & $5 / 33(15 \%)$ \\
\hline Enomoto et al. [29] & $37 / 0$ & $6 / 19(32 \%)$ \\
\hline Fujino et al. [30] & 79/n.a. & $3 / 28(11 \%)$ \\
\hline Jones et al. [31] & 35/n.a. & $2 / 13(15 \%)$ \\
\hline Kihana et al. [32] & $92 / 4$ & $23 / 72(32 \%)$ \\
\hline Peiffer et al. [33] & $39 / 7$ & $4 / 14(29 \%)$ \\
\hline Saegusa and Okayasu [34] & $92 / 0$ & $18 / 80(22.5 \%)$ \\
\hline Tashiro et al. [35] & $21 / 21$ & $18 / 18(100 \%)$ \\
\hline Tritz et al. [36] & $31 / 13$ & $14 / 30(47 \%)$ \\
\hline Koul et al. [37] & $50 / 5$ & $6 / 36(17 \%)$ \\
\hline Niederacher et al. [38] & $113 / 8$ & $18 / 67(26.9 \%)$ \\
\hline Tong et al. [39] & $30 / 8$ & $9 / 24(26.9 \%)$ \\
\hline Sirchia et al. [40] & $37 / 7$ & n.a./n.a. $(25.7 \%)$ \\
\hline Semczuk et al. [41] & $20 / 0$ & $1 / 19(5.3 \%)$ \\
\hline Liang et al. [42] & $19 / 19$ & $10 / 16(62.5 \%)$ \\
\hline Semczuk et al. [43] & $46 / 0$ & $8 / 42(19 \%)$ \\
\hline Graesslin et al. [44] & $43 / 5$ & $13 / 43(30.2 \%)$ \\
\hline
\end{tabular}

n.a. = Data not available. Only 3 TP53-mutated cases were analyzed for the allelic loss by Risinger et al. [6], which is why this study was not included in the table.

ed in tumors originating from genital tract organs, including ovarian [20-23], cervical [24-26] and endometrial $[6,27-44]$ carcinomas. Table 1 summarizes data presenting the prevalence of allelic loss at the TP53 locus in primary human ECs (divided into two subtypes). Representative examples of loss of heterozygosity $(\mathrm{LOH})$ at the TP53 locus are shown at figure 1A.

A high frequency of TP53 alterations has been described in UPSCs, subtype II uterine malignancies [4547], where approximately $90 \%$ of tumors revealed point mutations and an accumulation of $\mathrm{p} 53$ protein immunohistochemically [35, 42, 47-54]. Moreover, the unfavorable outcome of USPC patients has been attributed to TP53 mutations/p53 overexpression [55-60], suggesting that TP53 alterations may play an essential role in the development and progression of this EC subtype. Data presented by Ito et al. [61] revealed significantly poorer prognosis of EC patients with TP53 mutations than in those without mutations ( $p=0.033)$; however, the Cox proportional hazards regression model showed that only the clinical stage was an independent significant predictor

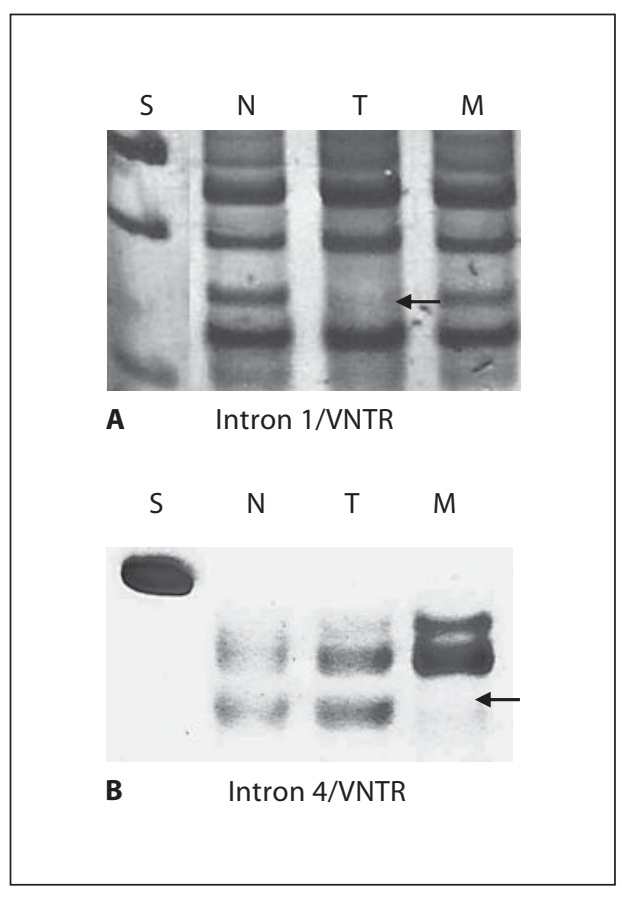

Fig. 1. A TP53 allelic loss present at intron 1/variable number of tandem repeats (VNTR) in primary human EC but not in the corresponding metastasis. B TP53 allelic loss present at intron 4/ VNTR in EC metastasis but not in the primary human EC. Arrows indicate the allelic loss. $\mathrm{S}=$ Molecular weight marker; $\mathrm{N}=$ normal DNA; $\mathrm{T}=$ tumor DNA; $\mathrm{M}=$ metastatic DNA.

of postoperative mortality. Interestingly, Koul et al. [62] reported that TP53 mutations were twice as frequent in tumors without hyperplasia than in neoplasms with hyperplasia. Finally they suggested that TP53 alterations represent an alternative route in subtype 2 EC development [62].

A higher frequency of $\mathrm{LOH}$ at the TP53 locus was reported by Liang et al. [42]. In that study, $62.5 \%$ of informative UPSCs revealed allelic imbalance. It is obvious that $\mathrm{LOH}$ at chromosome $17 \mathrm{p}$ has previously been identified in all informative UPSCs $(\mathrm{n}=18)$ and in 3 of $7(43 \%)$ informative endometrial intraepithelial carcinomas as a precursor lesion of UPSC [35].

\section{LOH TP53 and Clinicopathological Features of EC}

In the study conducted by Kihana et al. [32], the prevalence of LOH was significantly higher in poorly differentiated than in well and moderately differentiated uterine neoplasms ( $p=0.049)$, whereas none of other clinico- 
pathological variables of cancer was related to allelic loss. Altogether, 10 of 72 (14\%) tumors displayed TP53 point mutations and LOH, whereas a total of 33 (36\%) EC women showed point mutations, $\mathrm{LOH}$, or both genetic alterations simultaneously [32]. The overall number of allelic losses appears to increase with advanced tumor stage, thereby indicating the significant association between $\mathrm{LOH}$ accumulation and the progression of the disease [28]. Analysis of Southern blot hybridization using probes YNZ22 (D17S5) and MCT35.1 (D17S31) revealed allelic loss in 5 tumors: 2 clear-cell carcinomas (stages IA and IB due to the International Federation of Gynecology and Obstetrics, FIGO), 1 endometrioid-type uterine adenocarcinoma (stage IIB), and 2 advanced-stage (both at IVB stages of the disease) endometrioid-type ECs [28]. In another report, $\mathrm{LOH}$ was related to histological grading $(\mathrm{p}=0.03)$, advanced clinical stage of the disease $(\mathrm{p}=$ $0.01)$, and the presence of lymph node metastasis $(\mathrm{p}=$ $0.025)$ [34]. Myometrial invasion was not related to the frequency of $\mathrm{LOH}$ at TP53 locus only. $\mathrm{LOH}$, encompassing the highly polymorphic $(\mathrm{CA})_{25}$ di-nucleotide repeat at TP53, was studied in 65 primary human ECs by Koul et al. [37]. Allelic loss, detected in 17\% (6/36) of the informative cases, was significantly associated with TP53 point mutations $(\mathrm{p}=0.024)$. In the study conducted by Tritz et al. [36], the prevalence of allelic loss at chromosome 17 was much higher in type II tumors compared to type I ECs ( 87 vs. $22 \%$, respectively). It is worth pointing out that none of the atrophic or hyperplastic endometrial tissues were $\mathrm{LOH}$-positive. Moreover, endometrioid-type tumors revealed a higher frequency of $\mathrm{LOH}$ on the short arm of chromosome 17p (where the TP53 TSG is spanned) than on the long arm - 17q (87 and $62 \%$, respectively). As a conclusion, they suggested that alterations at $17 \mathrm{p} 13$ may preferentially be involved in human endometrial tumorigenesis. German scientists [38] have reported that the frequency of $\mathrm{LOH}$ at the TP53 locus correlates significantly with patient age ( $<50$ vs. $>50$ years old; $p=0.04$ ), histological grading ( $G 3$ vs. G2. vs. $G 1 ; p=0.015$ ), positive progesterone receptor status ( $\mathrm{p}=0.047)$, and no application of hormone replacement therapy $(\mathrm{p}=0.04)$. In another study, BRCA1, BRCA2, and TP53 allelic imbalances were assessed in a series of various human malignant tumors, including 30 sporadic ECs [39]. LOH at TP53 was significantly associated with allelic imbalance at $B R C A 2$, but not at BRCA1. These data were surprising for the authors because TP53 and BRCA2 genes are located on different human chromosomes, on 17p13.1 and 13q12-13, respectively. In a recent study published by Graesslin et al. [44], 13 of 43 (30.2\%) primary human ECs revealed
$\mathrm{LOH}$ at the TP53 locus. The frequency of $\mathrm{LOH}$ was significantly higher in papillary serous/clear cell (80\%) neoplasms than in endometrioid $(25 \%$; $p=0.03)$ and tamoxifen-induced $(16 \% ; p=0.01)$ uterine tumors. There was also statistically higher allelic loss between well and poorly differentiated neoplasms ( 6 and $60 \%$, respectively; $\mathrm{p}=$ 0.004 ), whereas the prevalence of $\mathrm{LOH}$ was not related to the clinical stage of the disease, depth of myometrial invasion, lymph node metastases, lymphovascular space invasion, recurrence, or death of the disease. Finally, ploidy status was not related to TP53 allelic imbalance [44].

Allelic loss at codon 72 has been shown in 32\% (6 of 19) of informative uterine tumors, but there was no significant link between allelic imbalance and the clinicopathological variables of cancer, including FIGO stage, histological grade, myoinvasion, or the existence of distant metastases [29].

In our previous study [41], 1 of 19 (5\%) informative ECs displayed allelic loss at TP53 locus, but none of the cases showed TP53 and $R b$ alterations simultaneously. These data suggest that $\mathrm{LOH}$ at TP53 and $R b$ occur independently of each other in primary ECs. In another report, there was no significant relationship between $\mathrm{LOH}$ TP53 and the clinical and pathologic features of cancer [43]. However, none of the 7 tumors associated with hyperplasia revealed allelic loss, whereas $30 \%$ (8 of 27 ) tumors without hyperplasia exhibited LOH $(\mathrm{p}=0.312)$. Finally, allelic imbalance was not related to MIB-1 proliferative index values in primary human ECs [43].

$\mathrm{LOH}$ and point mutations at TP53 have been reported in $35 \%$ (when the homozygous cases were excluded) and in $45 \%$ of uterine leiomyosarcomas, respectively, whereas both alterations have been reported in only 3 tumors [63]. There was no significant difference in patient survival between those cases with and those cases without LOH. As a final conclusion, the authors cannot exclude the possibility that TP53 alterations may be implicated in the progression of human uterine leiomyosarcomas [63].

\section{LOH TP53 and p53 Overexpression}

Human p53 protein comprises 393 amino acids and contains 3 domains: an $\mathrm{N}$-terminal transactivation domain, a central DNA-binding domain, and a C-terminal homo-oligomerization domain $[4,5]$. All three domains are necessary for efficient p53 activity, although the vast majority of genetic alterations within TP53 occur within the DNA-binding domain (amino acids 97-292) [4, 5, 6466]. It is worth pointing out that neither the acquisition 
Fig. 2. Various mechanisms causing p53 overexpression.

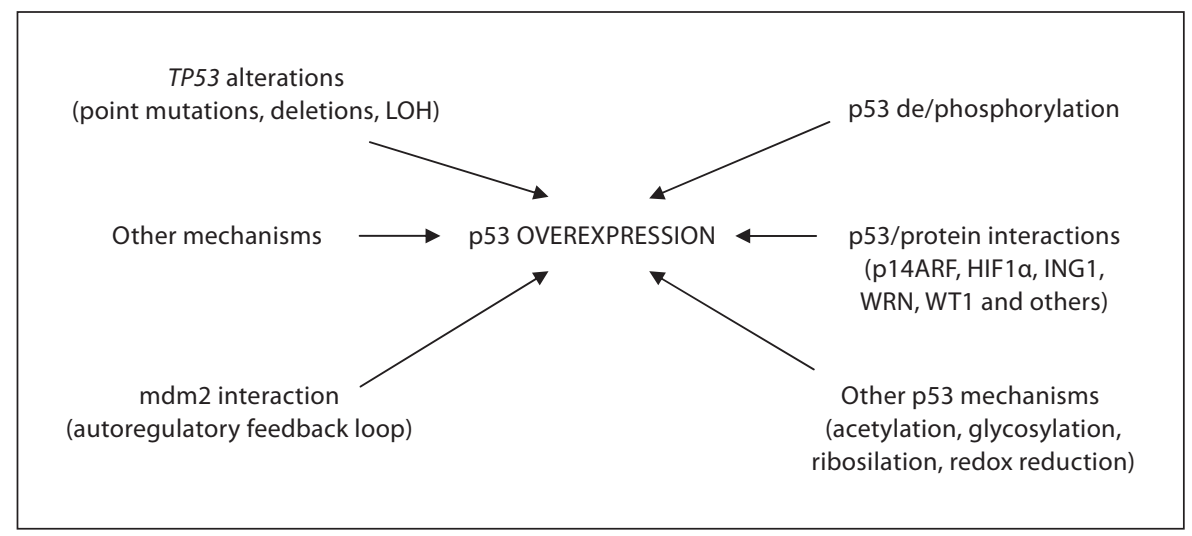

of the oncogenic function by the mutant p53 protein nor loss of normal p53 activity contribute to carcinogenesis. Overexpression of $\mathrm{p} 53$ may be caused by several different ways, including point mutations, gross deletions, allelic imbalance, or by interaction between p53 and cellular/ viral oncoproteins $[5,67]$ (fig. 2). In the literature, several p53 variants has been described; the human TP53 TSG can encode at least 9 different p53 isoforms: p53, p $53 \beta$, $\mathrm{p} 53 \gamma, \Delta 133 \mathrm{p} 53, \Delta 133 \mathrm{p} 53 \beta$ and $\Delta 133 \mathrm{p} 53 \gamma$ due to alternative splicing of the intron 9 and alternative initiation of translation or alternative splicing of the intron 2 [68-70]. Interestingly, the tissue-specific expression of these isoforms could explain the regulation of p53 transcriptional activity in normal and pathological human conditions. p53 isoform variants are expressed in several normal tissues and tumor samples; however, novel specific p53 isoform antibodies are still being generated [70]. Most of the p53 isoforms showed increased stability compared to wild-type protein $[5,70]$.

Overexpression of p53, detected by immunohistochemistry, is common in malignant tumors, although the frequency rate is different in various human neoplasms [67]. In our previous report [50], p53 overexpression correlates significantly with the advanced clinical stage of human ECs (I/II vs. III/IV, $\mathrm{p}=0.02$ ). A population-based study performed by Salvesen et al. [71] revealed that p53 overexpression (staining index $>4$ ), apart from patient age, FIGO stage, MVD, and Ki-67, showed an unfavorable prognostic impact for EC patients. The results of their study were in line with several data indicating an independent prognostic significance of p53 overexpression in primary human ECs [72-79]. By contrast, however, Inoue et al. [80] reported that p53 overexpression itself does not appear to be an independent prognostic factor in primary human ECs. Interestingly, Coronado et al. [81] previously demonstrated that p53 overexpression was an independent predictor of recurrent disease in ECs, even better than HER-2/neu overexpression. In another report, overexpression of $\mathrm{p} 53$ was significantly predictive for recurrent EC; however, protein immunoreactivity was mostly not correlated with TP53 point mutations [82]. From the clinical point of view, determination of p53 status could identify high-risk patients who may develop recurrence even after aggressive surgical management. It is worth citing the gentle study conducted by Ohkouchi et al. [83], who reported a statistically significant difference in the 5-year survival rate of women with stage III/IV disease without and with p53 overexpression (75 and $40 \%$, respectively). These authors recommended an aggressive strategy for advanced-stage EC women affected by tumors overexpressing p53. Previously, Mariani et al. [84] suggested an evaluation of the ploidy status, MIB-1, and p53 overexpression in preoperative EC samples to stratify patients into low- and high-risk groups before the inclusion of a definitive anticancer therapy.

Only a few reports have evaluated the relationship between TP53 alterations (including LOH study) with p53 overexpression in primary human ECs. Increased p53 level has been reported in all $\mathrm{mdm} 2$-positive ECs without detectable TP53 alterations, suggesting that p53 may be stabilized and inactivated by complex formation with $\mathrm{mdm} 2$ [8]. Mdm2 is an E3 ligase, promoting p53 degradation through a ubiquitin-dependent pathway on nuclear and cytoplasmic proteosomes $[85,86]$. In general, $\mathrm{mdm} 2$ inhibits p53 cellular activity by different ways including binding to the transactivation domain of p53, by targeting p53 for ubiquitination, by inhibiting acetylation of p53 and by shutting p53 to the cytoplasm [5]. Moreover, $\mathrm{mdm} 2$ plays an important role in regulating the subcellular localization of p53 [87, 88]. Its ligase activity contrib- 
utes to the efficient nuclear export of p53, possibly by driving p53 into a monomeric variant [89].

Another study found no significant association between p53 immunopositivity and the presence of allelic loss at TP53 [34]. Data from our laboratory also revealed the lack of a relationship between overexpression of p53 and the allelic imbalance at TP53 locus [43]. Similar to the all above-mentioned data, Graesslin et al. [44] recently failed to reveal a relationship between LOH TP53 and quantitative p53 overexpression. Altogether, overexpression of $\mathrm{p} 53$ does not seem to be related to allelic imbalance at TP53 in primary human ECs. As an explanation, allelic imbalance at $17 \mathrm{p}$ may be connected with whole chromosome loss [22], with a subsequent lack of p53 immunoreactivity. On the other hand, $\mathrm{mdm} 2$ binds to the transcription activation domain in the $\mathrm{N}$-terminus of $\mathrm{p} 53$ and also promotes the degradation of this protein by the ubiquitin-proteasome system $[85,86]$. By contrast, phosphorylation that could inhibit $\mathrm{mdm} 2$ binding to p53 may be involved in the regulation of p53 cellular localization, probably by enhancing the nuclear accumulation of this protein [89-91] (fig. 2). Other proteins, for example Mot2, bcl-2 or calcium-dependent protein kinase $C$, may also be involved in the regulation of p53 [65]. Finally, the application of commercially available different anti-p53 antibodies, various methods of detection, antigen retrieval techniques, and immunostaining criteria complicate the comparison between the different studies [64].

\section{Prognostic Relevance of Allelic Loss at TP53}

The prognostic relevance of the immunoreactivity of various receptors, cell-cycle proliferation markers, oncogenes, and TSGs in endometrial neoplasia was reviewed previously by Sivridis and Giatromanolaki [91] and Prat [92]. They reported that p53 overexpression was associated with an unfavorable outcome of patients affected by primary EC. However, a limited number of studies have provided data addressing the prognostic relevance of allelic loss at TP53 in primary human ECs $[32,38,43]$. The first study dealing with this topic was published by $\mathrm{Ki}$ hana et al. [32] where 85 of 92 (93\%) cases were of endometrioid-type ECs. LOH TP53 was an indicator of a unfavorable outcome that was independent of tumor stage, histologic grade or muscular invasion by Cox regression analysis ( $\mathrm{p}=0.015$; OD 1.681; RR 5.07). Kaplan-Meier analysis also revealed that EC patients with LOH TP53 had a significantly shorter survival compared to patients lacking allelic loss either in stages I-IV $(p=0.002)$ or in stage I alone $(\mathrm{p}=0.009)$. They finally suggested that $\mathrm{LOH}$ TP53 may accumulate through the various steps of EC development. By contrast, LOH at TP53 did not correlate significantly with disease-free survival or overall survival in 113 patients affected by endometrial cancer $(93 \%$ of the tumors were of endometrioid type) [38]. However, the main bias of their study was the application of only one genetic marker (AFM051). A previous study conducted at our laboratory revealed a tendency towards a poorer outcome of women affected by uterine corpus cancer displaying LOH ( $p=0.093)$. Most of our cases $(96 \%)$ were of endometrioid-type ECs, but no multivariate analysis was performed therewithal. We finally suggest that the evaluation of LOH at TP53 may affect a subgroup of ECs characterized by an unfavorable prognosis, and allelic positive group should undergo careful treatment modalities.

\section{LOH at TP53 Locus in Metastatic ECs}

Development of metastasis is the most dangerous manifestation of tumor progression and is the main cause of death for oncological patients. Metastatic cells form a complex of several unfavorable signs associated with the acquisition of neoangiogenesis and the dysregulation of the whole genetic machinery [93-96]. Although EC is the most common malignancy of the female genital tract, with 4,196 new incidences in Poland in 2005, only 2.3-5\% of the cases are widespread at the time of primary diagnosis [97]. The prognosis of EC patients with disseminated uterine cancer is in general poor, with overall survival of $<20 \%$ after 5 years [97]. ECs spread primarily to the pelvic and para-aortic lymph nodes, and to the adnexa and omentum $[98,99]$. Distant metastases, for example to the brain $[100,101]$, lungs [102-104], or bones $[105,106]$, have also been described. Moreover, this cancer type can incidentally metastasize to the scalp [107], iris [108], mandible [109], pleura [110], or to the pancreas [111].

The exact genetic mechanisms implicated in the development process of EC metastases (either in animal models or in humans) are not fully recognized [112-116]. Based on the data published in the literature, there are several reports dealing with allelic loss at the TP53 locus in primary human ECs, whereas data assessing the prevalence of allelic imbalance in metastatic ECs are scarce (a representative image of LOH TP53 in metastatic EC is shown in fig. 1B). Previously, Jones et al. [31] found no significant relationship between lymph node metastases and the incidence of $\mathrm{LOH}$ at any particular locus, includ- 
ing LOH on chromosome 17p. Similarly, the LOH TP53 pattern did not correlate with the presence of metastases to the lymph nodes $[32,43]$ or to other organs [38]. By contrast, there was a significant linkage between TP53 LOH and lymph node metastases in a Japanese study [34]. The data from our laboratory [117] recently showed differences in the frequency of allelic imbalance at TP53 between primary ECs and corresponding metastases. The coexistence of allelic loss at TP53 in primary ECs and corresponding metastatic lesions at introns 1 and 4 was detected in only $9 \%$. We finally stated that allelic imbalance at TP53 may be associated not only with primary uterine tumors but also with corresponding metastases, although this phenomenon was not shown in all cases [117]. Evaluation of LOH at TP53 should be performed in a large group of type II ECs to precisely evaluate the prognostic value of this alteration in aggressive endometrial neoplasms.

\section{Perspectives}

Although the molecular findings reported herein may be of limited clinical value, the unique molecular phenotype among cancer subtypes is important to better understand the pathogenesis and to develop new target ther- apeutic modalities for future applications [118]. It is well known that acquisition of the TP53 alterations leads to the development of virulent, subtype II EC (estrogen 'independent'), which is not transited through a hyperplastic endometrium and is associated with a rapid and uncontrolled growth. Allelic loss should be investigated in these cancer subtypes to verify the exact role of TP53 allelic imbalance during the formation of metastases. In addition, as suggested by Velasco et al. [13], analysis of allelic loss is a very good tool to identify new TSGs and to find out which inactivation may be implicated, apart from TP53, in wide-spreading uterine cancers. Finally, $\mathrm{LOH}$ analysis (including allelic loss at TP53) has been widely used to distinguish synchronous primary ovarian and endometrial cancers and metastatic lesions [119, 120]. In such cases, however, molecular genetic data should be interpreted with great caution, and in coexistence with the clinical and pathological variables available [121].

\section{Acknowledgments}

This study was supported by a grant from the Medical University of Lublin, Lublin, Poland (Dz. St. 326/09) to A.S. The authors would like to acknowledge Mr. Bernd Wuesthoff for careful editing of the manuscript.

\section{References}

1 Hollstein M, Sidransky D, Vogelstein B, Harris CC: 53 mutations in human cancers. Science 1991;253:49-53.

2 Hainaut P, Hollstein M: $p 53$ and human cancer: the first ten thousand mutations. Adv Cancer Res 2000;77:81-137.

3 Miturski R, Bogusiewicz M, Ciotta C, Bignami M, Gogacz M, Burnouf D: Mismatch repair genes and microsatellite instability as molecular markers for gynecological cancer detection. Exp Biol Med (Maywood) 2002; 227:579-586.

4 Oren M: Regulation of the p53 tumor suppressor protein. J Biol Chem 1999;274: 36031-36034.

5 Balint E, Vousden KH: Activation and activities of the p53 tumour suppressor protein. Br J Cancer 2001;85:1813-1823.

6 Risinger JI, Dent GA, Ignar-Trowbridge D, McLachlan JA, Tsao MS, Senterman M, Boyd $\mathrm{J}:$ p53 gene mutations in human endometrial carcinoma. Mol Carcinog 1992;5:250-253.

Allelic Loss at TP53 in Endometrial Cancer
7 Honda T, Kato H, Imamura T, Gima T, Nishida JI, Sasaki M, Hoshi K, Sato A, Wake N: Involvement of p53 gene mutations in human endometrial carcinomas. Int J Cancer 1993;53:963-967.

8 Skomedal H, Kristensen GB, Nesland JM, Borrensen-Dale AL, Trope C, Holm R: TP53 alterations in relation to the cell cycle-associated proteins p21, cyclin D1, CDK4, RB, MDM2, and EGFR in cancers of the uterine corpus. J Pathol 1999;187:556-562.

9 Lax SF: Dualistic model of molecular pathogenesis in endometrial carcinoma. Zentralbl Gynecol 2002;124:10-16.

10 Koul A, Willen R, Bendahl PO, Nilbert M, Borg A: Distinct sets of gene alterations in endometrial carcinoma implicate alternate modes of tumorigenesis. Cancer 2002;94: 2369-2379.

11 Sakuragi N, Watari H, Ebina Y, Yamamoto R, Steiner E, Koelbl H, Yano M, Tada M, Moriuchi T: Functional analysis of $p 53$ gene and the prognostic impact of dominant-negative p53 mutation in endometrial cancer. Int J Cancer 2005; 116:514-519.
12 Soufir N, Queille S, Liboutet M, Thibaudeau O, Bachelier F, Delestaing G, Balloy BC, Breuer J, Janin A, Dubertret L, Vilmer $\mathrm{C}$, Basset-Seguin $\mathrm{N}$ : Inactivation of the CDKN2A and the p53 tumour suppressor genes in external genital carcinomas and their precursors. Br J Dermatol 2007;156: 448-453.

13 Velasco A, Pallares J, Santacana M, Yeramian A, Dolcet X, Eritja N, Puente S, Sorolla A, Llecha N, Matias-Guiu X: Loss of heterozygosity in endometrial carcinoma. Int J Gynecol Pathol 2008;27:305-317.

14 Knudson AG Jr: Mutation and cancer: statistical study of retinoblastoma. Proc Natl Acad Sci USA 1971;68:820-823.

15 Hecht JL, Mutter GL: Molecular and pathologic aspects of endometrial carcinogenesis. J Clin Oncol 2006;24:4783-4791.

16 Ronnett BM, Zaino RJ, Ellenson LH, Kurman RJ: Endometrial carcinoma; in Kurman RJ (ed): Blaustein's Pathology of the Female Genital Tract, ed 5. New York, Springer, 2002, pp 501-559. 
17 Prat J, Gallardo A, Cautrecasas M, Catasus L: Endometrial carcinoma: pathology and genetics. Pathology 2007;39:72-87.

18 Doll A, Abal M, Rigau M, Monge M, Gonzalez M, Demajo S, Colas E, Llaurado M, Alazzouzi H, Planaguma J, Lohmann MA, Garcia J, Castellvi S, Ramon y Cajal J, Gil-Moreno A, Xercavins J, Alameda F, Reventos J: Novel molecular profiles of endometrial cancer new light through old windows. J Steroid Biochem Mol Biol 2008;108:221-229.

19 Knuutila S, Aalto Y, Autio K, Bjorkqvist AM, El-Rifai W, Hemmer S, Huhta T, Kettunen E, Kiuru-Kuhlefelt S, Larramendy ML, Lushnikova T, Monni O, Pere H, Tapper J, Tarkkanen M, Varis A, Wasenius VM, Wolf M, Zhu Y: DNA copy number losses in human neoplasms. Am J Pathol 1999;155:683-694.

20 Okamoto A, Sameshima Y, Yokoyama S, Tareshima Y, Sugimura T, Terada M, Yokota $\mathrm{J}$ : Frequent allelic losses and mutations of the p53 gene in human ovarian cancer. Cancer Res 1991;51:5171-5176.

21 Phillips NJ, Ziegler MR, Radford DM, Fair KL, Steinbrueck T, Xynos FP, Donis-Keller $\mathrm{H}$ : Allelic deletion on chromosome 17p13.3 in early ovarian cancer. Cancer Res 1996;56: 606-611.

22 Eccles DM, Russell SE, Haites NE, Atkinson R, Bell DW, Gruber L, Hickey I, Kelly K, Kitchener H, Leonard L: Early loss of heterozygosity on $17 \mathrm{q}$ in ovarian cancer. The Abe Ovarian Cancer Genetics Group. Oncogene 1992:7:2069-2072.

23 Skilling JS, Powills K, Lager DJ, Anderson B, Sorosky J, Buller RE: p53 allelotypes and enhanced detection of allelic loss in ovarian cancer: Lack of correlation with familiar and clinical factors. Gynecol Oncol 1996;61:180188.

24 Park SY, Kang YS, Kim BG, Lee SH, Lee ED, Lee KH, Park KB, Lee JH: Loss of heterozygosity on the short arm of chromosome 17 in uterine cervical carcinomas. Cancer Genet Cytogenet 1995;79:74-78.

25 Kim JW, Lee CG, Han SM, Kim KS, Kim JO, Lee JM, Kim IK, Namkoong SE: Loss of heterozygosity of the retinoblastoma and p53 genes in primary cervical carcinomas with human papillomavirus infection. Gynecol Oncol 1997;67:215-221.

26 Wistuba II, Montellano FD, Milchgrub S, Virmani AK, Behrens C, Chen H, Ahmadian M, Nowak JA, Muller C, Minna JD, Gazdar AF: Deletions of chromosome $3 p$ are frequent and early events in the pathogenesis of uterine cervical carcinoma. Cancer Res 1997; 57:3154-3158.

27 Okamoto A, Sameshima Y, Yamada Y, Teshima SI, Terashima Y, Terada M, Yokota J: Allelic loss on chromosome 17 and p53 mutations in human endometrial carcinoma of the uterus. Cancer Res 1991;51:5632-5636.
28 Imamura T, Arima T, Kato H, Miyamoto S, Sasazuki T, Wake N: Chromosomal deletions and K-ras gene mutations in human endometrial carcinomas. Int J Cancer 1992;51: 47-52.

29 Enomoto T, Fujita M, Inoue M, Rice JM, Nakajima R, Tanizawa O, Nomura T: Alterations of the $p 53$ tumor suppressor gene and its association with activation of the $\mathrm{c}-\mathrm{K}$ ras- 2 protooncogene in premalignant and malignant lesions of the human uterine endometrium. Cancer Res 1993;53:1883-1888.

30 Fujino T, Risinger JI, Collins NK, Liu FS, Nishii H, Takahashi H, Westphal EM, Barrett JC, Sasaki H, Kohler MF, Bechuck A, Boyd J: Allelotype of endometrial carcinoma. Cancer Res 1994;54:4294-4298.

31 Jones MH, Koi S, Fujimoto I, Hasumi K, Kato K, Nakamura Y: Allelotype of uterine cancer by analysis of RFLP and microsatellite polymorphisms: Frequent loss of heterozygosity on chromosome arms $3 \mathrm{p}, 9 \mathrm{q}, 10 \mathrm{q}$, and $17 \mathrm{p}$. Genes Chromosomes Cancer 1994;9:119123.

32 Kihana T, Hamada K, Inoue Y, Yano N, Iketani $\mathrm{H}$, Murao SI, Ukita M, Matsuura S: Mutation and allelic loss of the p53 gene in endometrial carcinoma. Incidence and outcome in 92 surgical patients. Cancer 1995;76: $72-78$.

33 Peiffer SL, Herzog TJ, Tribune DJ, Mutch DG, Gersell DJ, Goodfellow PJ: Allelic loss of sequences from the long arm of chromosome 10 and replication errors in endometrial cancers. Cancer Res 1995;55:1922-1926.

34 Saegusa M, Okayasu I: Bcl-2 is closely correlated with favorable prognostic factors and inversely associated with p53 protein accumulation in endometrial carcinomas: immunohistochemical and polymerase chain reaction/loss of heterozygosity findings. J Cancer Res Clin Oncol 1997;123:429-434.

35 Tashiro H, Isacson C, Levine R, Kurman RJ, Cho KR, Hedrick L: p53 gene mutations are common in uterine serous carcinoma and occur early in their pathogenesis. Am J Pathol 1997;150:177-185.

36 Tritz D, Pieretti M, Turner S, Powell D: Loss of heterozygosity in usual and special variant carcinomas of the endometrium. Hum Pathol 1997;28:607-612.

37 Koul A, Borg A, Pejovic T, Bendahl PO, Hogberg T, Iosif CS, Killander D: Identification of TP53 gene mutations in uterine corpus cancer with short follow-up. Gynecol Oncol 1997;67:295-302.

38 Niederacher D, An HX, Camrath S, Dominik SI, Gohring UJ, Oertel A, Grass M, Hantschmann P, Lordnejad MR, Beckmann MW: Loss of heterozygosity of BRCA1, TP53 and TCRD markers analysed in sporadic endometrial cancer. Eur J Cancer 1998;34 1770-1776.
39 Tong D, Kucera E, Schuster E, Schmutzler RK, Swoboda H, Reinthaller A, Leopolter S, Zeillinger R: Loss of heterozygosity ( $\mathrm{LOH})$ at p53 is correlated with $\mathrm{LOH}$ at BRCA1 and $B R C A 2$ in various human malignant tumors. Int J Cancer 2000;88:319-322.

40 Sirchia SM, Sironi E, Grati FR, Serafini P, Garagiola I, Rossella F, Dulcetti F, Pardi G, Garsia S, Simoni G: Losses of heterozygosity in endometrial adenocarcinomas: Positive correlations with histopathological parameters. Cancer Genet Cytogenet 2000;121: 156-162.

41 Semczuk A, Marzec B, Roessner A, Jakowicki JA, Wojcierowski J, Schneider-Stock R: Loss of heterozygosity of the retinoblastoma gene is correlated with the altered $\mathrm{pRb}$ expression in human endometrial cancer. Virchows Arch 2002,441:577-583.

42 Liang SX, Chambers SK, Cheng L, Zhang S, Zhou Y, Zheng W: Endometrial glandular dysplasia: a putative precursor lesion of uterine papillary serous carcinoma. Part II: Molecular features. Int J Surg Pathol 2004;12: 319-331.

43 Semczuk A, Marzec B, Skomra D, Roessner A, Cybulski M, Rechberger T, SchneiderStock R: Allelic loss at TP53 is not related to p53 protein overexpression in primary human endometrial carcinomas. Oncology 2005;69:317-325.

44 Graesslin O, Chantot-Bastaraud S, Lorenzato M, Birembaut P, Quereux C, Darai E: Fluorescence in situ hybridization and immunohistochemical analysis of p53 expression in endometrial cancer: prognostic value and relation to ploidy. Ann Surg Oncol 2008; 15 : 484-492.

45 Bokhman JV: Two pathogenetic types of endometrial carcinoma. Gynecol Oncol 1983; 15:10-17.

46 Deligdisch L, Holinka CF: Endometrial carcinoma: two diseases? Cancer Detect Prev 1987; 10:237-246.

47 Sherman ME: Theories of endometrial carcinogenesis: a multidisciplinary approach. Mod Pathol 2000;13:295-308.

48 King SA, Adas AA, Livolsi VA, Takahashi H, Behbakht K, McGovern P, Benjamin I, Rubin SC, Boyd J: Expression and mutation analysis of the p53 gene in uterine papillary serous carcinoma. Cancer 1995;75:2700-2705.

49 Sherman ME, Bur ME, Kurman RJ: p53 in endometrial cancers and its putative precursors: evidence for diverse pathways of tumorigenesis. Hum Pathol 1995;26:12681274 .

50 Semczuk A, Miturski R, Tomaszewski J, Putowski LT, Jakowicki JA: Assessment of p53 protein expression in human endometrial carcinomas. Ginekol Pol 1996;67(suppl 6):119-123.

51 Moll UM, Chalas E, Auguste M, Meaney D, Chumas J: Uterine papillary serous carcinoma evolves via a p53-driven pathway. Hum Pathol 1996;27:1295-1300. 
52 Lax SF, Kurman RJ: A dualistic model for endometrial carcinogenesis based on immunohistochemical and molecular genetic analyses. Verh Dtsch Ges Pathol 1997;81:228-232.

53 Kovalev S, Marchenko ND, Gugliotta BG, Chalas E, Chumas J, Moll UM: Loss of p53 function in uterine papillary serous carcinoma. Hum Pathol 1998;29:613-619.

54 Lax SF, Kendall B, Tashiro H, Slebos RJ, Hendrick L: The frequency of p53, K-ras mutations, and microsatellite instability differs in uterine endometrioid and serous carcinoma. Evidence of distinct molecular genetic pathways. Cancer 2000;88:814-824.

55 Bancher-Todesca D, Gitsch G, Williams KE, Kohlberger P, Neunteufel W, Obermair A, Heinze G, Breitenecker G, Hacker NF: p53 protein overexpression: a strong prognostic factor in uterine papillary serous carcinoma. Gynecol Oncol 1998;71:59-63.

56 Sung CJ, Zheng Y, Quddus MR, Kang X, Zhang Z-F, Lauchlan SC, Zcheng W: p53 as a significant prognostic marker in endometrial carcinoma. Int J Gynecol Cancer 2000;10: 119-127.

57 Lax SF: Molecular genetic pathways in various types of endometrial carcinoma: from a phenotypical to a molecular-based classification. Virchows Arch 2004;444:213-223.

58 Liu Z, Wan G, Healpy C, Bisoffi M, Griffith $\mathrm{JK}, \mathrm{Hu} \mathrm{CA}$ : A novel loss-of-function mutation in TP53 in an endometrial cancer cell line and uterine papillary serous carcinoma model. Mol Cell Biochem 2007;297:179-187.

59 Inoue M: Current molecular aspects of the carcinogenesis of the uterine endometrium. Int J Gynecol Cancer 2001;11:339-348.

60 Prat J, Gallardo A, Cuatrecases M, Catasus L: Endometrial carcinoma: pathology and genetics. Pathology 2007;39:72-87.

61 Ito K, Sasano H, Matsunaga G, Sato S, Yajima A, Nasim S, Garret CT: Correlations between p21 expression and clinicopathological findings, p53 gene and protein alterations, and survival in patients with endometrial carcinoma. J Pathol 1997;183:318-324.

62 Koul A, Willen R, Bendahl PO, Nilberg M, Borg A: Distinct sets of gene alterations in endometrial carcinoma implicate alternate modes of tumorigenesis. Cancer 2002;94: 2369-2379.

63 Zhai YL, Nikaido T, Orii A, Horiuchi A, Toki T, Fujii S: Frequent occurrence of loss of heterozygosity among tumor suppressor genes in uterine leiomyosarcoma. Gynecol Oncol 1999;75:453-459.

64 Hayat MA: Microscopy, Immunohistochemistry, and Antigen Retrieval Methods: For Light and Electron Microscopy. New York, Kluver Academic/Plenum, 2002.

65 Liang SH, Clarke MF: Regulation of p53 localization. Eur J Biochem 2001;268:27792783.

66 Lane D: Anthony Dipple Carcinogenesis Award. p53 from pathway to therapy. Carcinogenesis 2004;25:1077-1081.
67 Soong R, Robbins PD, Dix BR, Grieu F, Lim B, Knowles S, Williams KE, Turbett GR, House AK, Iacopetta BJ: Concordance between p53 protein overexpression and gene mutation in a large series of common human carcinomas. Hum Pathol 1996;27:10501055.

68 Ghosh A, Steward D, Maltashewski G: Regulation of human p53 activity and cell localization by alternative splicing. Mol Cell Biol 2004;24:7987-7997.

69 Bourdon JC, Fernandes K, Murray-Zmijewski F, Liu G, Diot A, Xirodimas DP, Saville MK, Lane DP: p53 isoforms can regulate p53 transcriptional activity. Genes Dev 2005; 19 : 2122-2137.

70 Bourdon JC: p53 and its isoforms in cancer Br J Cancer 2007;97:277-282.

71 Salvesen HB, Iversen OE, Akslen LA: Prognostic significance of angiogenesis and $\mathrm{Ki}$ $67, p 53$, and $p 21$ expression: a populationbased endometrial carcinoma study. J Clin Oncol 1999;17:1382-1390.

72 Pisani AL, Barbuto DA, Chen D, Ramos L, Lagasse LD, Karlan BY: HER-2/neu, p53, and DNA analyses as prognosticators for survival in endometrial carcinoma. Obstet Gynecol 1995;85:729-734.

73 Kohlberger P, Gitsch G, Loesh A, Tempfer C, Kaider A, Reinthaller A, Kainz C, Breitenecker G: p53 protein overexpression in early stage endometrial cancer. Gynecol Oncol 1996;62:213-217.

74 Hamel NW, Sebo TJ, Wilson TO, Keeney GL, Roche PC, Suman VJ, Hu TC, Podratz KC: Prognostic value of p53 and proliferating cell nuclear antigen expression in endometrial carcinoma. Gynecol Oncol 1996;62:192-198.

75 Soong R, Knowles S, Williams KE, Hammond IG, Wysocki SJ, Iacopetta BJ: Overexpression of p53 protein is an independent prognostic indicator in human endometrial carcinoma. Br J Cancer 1996;74:562-567.

76 Kohler MF, Carney P, Dodge R, Soper JT, Clarke-Pearson DL, Marks JR, Berchuck A: p53 overexpression in advanced-stage endometrial adenocarcinoma. Am J Obstet Gynecol 1996; 175:1246-1252.

77 Ito K, Sasano H, Matsunaga G, Sato S, Yajima A, Nasim S, Garret CT: Correlations between p21 expression and clinicopathological findings, p53 gene and protein alterations, and survival in patients with endometrial carcinoma. J Pathol 1997;183:318-324.

78 Geisler JP, Geisler HE, Wiemann MC, Zhou Z, Miller GA, Crabtree W: p53 expression as a prognostic indicator of 5-year survival in endometrial cancer. Gynecol Oncol 1999;74: 468-471.

79 Jongen $\mathrm{VH}$, Briet JM, de Jong RA, Joppe E, ten Hoor KA, Boezen HM, Evans DB, Hollema $H$, van der Zee AG, Nijman HW: Aromatase, cyclooxygenase 2, HER-2/neu, and p53 as prognostic factors in endometrioid endometrial cancer. Int J Gynecol Cancer 2009;19:670-676.
80 Inoue M, Okayama A, Fujita M, Enomoto T, Sakata M, Tanizawa O, Ueshima H: Clinicopathological characteristics of p53 overexpression in endometrial cancers. Int J Cancer 1994;58:14-19.

81 Coronado PJ, Vidart JA, Lopez-Asenjo JA, Fasero M, Furio-bacete V, Magrina J, Escudero M: P53 overexpression predicts endometrial carcinoma recurrence better than HER-2/neu overexpression. Eur J Obstet Gynecol Reprod Biol 2001;98:103-108.

82 Pijnenborg JM, van de Broek L, Dam de Veen GC, Roemen GM, de Haan J, van Engeland M, Voncken JW, Groothuis PG: TP53 overexpression in recurrent endometrial carcinoma. Gynecol Oncol 2006;100:397-404.

83 Ohkouchi T, Sakuragi N, Watari H, Nomura E, Todo Y, Yamada H, Fujimoto S: Prognostic significance of Bcl-2, p53 overexpression, and lymph node metastasis in surgically staged endometrial carcinoma. Am J Obstet Gynecol 2002;187:353-359.

84 Mariani A, Sebo TJ, Katzmann JA, Keeney GL, Roche PC, Lesnick TG, Podratz KC: Pretreatment assessment of prognostic indicators in endometrial cancer. Am J Obstet Gynecol 2000;182:1535-1544

85 Michael D, Oren M: The p53-Mdm2 module and the ubiquitin system. Semin Cancer Biol 2003;13:49-58.

86 Moll UM, Petrenko O: The MDM2-p53 interaction. Mol Cancer Res 2003;1:10011008

87 Momand J, Zambetti GP, Olson DC, George $\mathrm{D}$, Levine AJ: The mdm-2 oncogene product forms a complex with the $\mathrm{p} 53$ protein and inhibits p53-mediated transactivation. Cell 1992;69:1237-1245.

88 Haupt Y, Maya R, Kazaz A, Oren M: Mdm2 promotes the rapid degradation of $\mathrm{p} 53 . \mathrm{Na}$ ture 1997;387:296-299.

89 Kubuttat MH, Jones SM, Vousden KH: Regulation of p53 stability by Mdm2. Nature 1997;387:299-303.

90 Jęczeń R, Skomra D, Cybulski M, SchneiderStock R, Szewczuk W, Roessner A, Rechberger T, Semczuk A: P53/MDM2 overexpression in metastatic endometrial cancer: correlation with clinicopathological features and patient outcome. Clin Exp Metastasis 2007;24:503-511.

91 Sivridis E, Giatromanolaki A: Prognostic aspects on endometrial hyperplasia and neoplasia. Virchows Arch 2001;439:118-126.

92 Prat J: Prognostic parameters of endometrial carcinoma. Hum Pathol 2004;35:649-662.

93 Webb CP, Vande Woude GF: Genes that regulate metastasis and angiogenesis. J Neurooncol 2000;50:71-87.

94 Yokota J: Tumor progression and metastasis. Carcinogenesis 2000;21:497-503.

95 Coomber BL, Yu JL, Fathers KE, Plumb C, Rak JW: Angiogenesis and the role of epigenetics in metastasis. Clin Exp Metastasis 2003;20:215-227. 
96 Hoon DSB, Kitago M, Kim J, Mori T, Piris A, Szyfelbein K, Mihm MC Jr, Nathanson SD, Padera TP, Chambers AF, Vantyghem SA, MacDonald IC, Shivers SC, Alsarraj M, Reitgen DS, Passlick B, Sienel W, Pantel K: Molecular mechanisms of metastasis. Cancer Metastasis Rev 2006;25:203-220.

97 Hacker NF: Uterine cancer; in Berek JS, Hacker NF (eds): Practical Gynecologic Oncology, ed 4. Philadelphia, Lippincott Williams \& Wilkins, 2005, pp 397-442.

98 Mariani A, Webb MJ, Keeney GL, Podratz KC: Routes of lymphatic spread: a study of 112 consecutive patients with endometrial cancer. Gynecol Oncol 2001;81:100-104.

99 Mariani A, Keeney G, Aletti G, Webb MJ, Haddock MG, Podratz KC: Endometrial carcinoma: paraaortic dissemination. Gynecol Oncol 2004;92:833-838.

100 Cormio G, Lissoni A, Losa G, Zanetta G, Pellegrino A, Mangioni C: Brain metastases from endometrial carcinoma. Gynecol Oncol 1996;61:40-43.

101 Martinez-Manas RM, Brell M, Rumia J, Ferrer E: Brain metastases in endometrial carcinoma. Gynecol Oncol 1998;70:282284.

102 Bouros D, Papadakis K, Siafakas N, Fuller AF Jr: Patterns of pulmonary metastasis from uterine cancer. Oncology 1996;53: 360-363.

103 Mariani A, Webb MJ, Keeney GL, Calori G, Podratz KC: Hematogenous dissemination in corpus cancer. Gynecol Oncol 2001;80: 233-238.

104 Schols WA, Kock HCLV, van Etten FHPM: Recurrent endometrial adenocarcinoma presenting as a solitary humeral metastasis. Gynecol Oncol 1995;59:148-150.

105 Sahinler I, Erkal H, Akyazici E, Atkovar G, Okkan S: Endometrial carcinoma as an unusual presentation of bone metastasis: a case report. Gynecol Oncol 2001;82:216218.
106 Landoni F, Lazzaro G, Lazzari R, Testori A: Endometrial carcinoma bone metastases in unusual sites. Gynecol Oncol 2006;102: 411-414.

107 Mustafa MS, Al-Nuaim L, Inayat-Ur-Rahman $\mathrm{N}$ : Scalp and cranial bone metastasis of endometrial carcinoma: a case report and literature review. Gynecol Oncol 2001; 81:105-109.

108 Capeans C, Santos L, Sanchez-Solario M, Forteza J: Iris metastasis from endometrial carcinoma. Ophthalmology 1994;101:432438.

109 Dorosetz DE, Orr JW, Salenius SA, Orr PF: Mandibular metastasis in a patient with endometrial cancer. Gynecol Oncol 1999;72: 243-245.

110 Semczuk A, Skomra D, Rybojad P, Jęczeń R, Rechberger T: Endometrial carcinoma with pleural metastasis: a case report. Acta Cytol 2006;50:697-700.

111 Oshiro H, Miyagi Y, Kawaguchi Y, Rino Y, Arai $\mathrm{H}$, Asai-Sato M, Nakayama $\mathrm{H}$, Yamanaka S, Inayama Y, Fukushima N: Endometrial carcinoma without myometrial invasion metastasizing to the pancreas and masquerading as primary pancreatic neoplasm. Pathol Int 2008;58:456-461.

112 Vollmer G: Endometrial cancer: experimental models useful for studies on molecular aspects of endometrial cancer and carcinogenesis. Endocr Relat Cancer 2003;10 23-42.

113 Dery MC, Van Themsche C, Provencher D, Mes-Masson AM, Asselin E: Characterization of EN-1078D, a poorly differentiated human endometrial carcinoma cell line: a novel tool to study endometrial invasion in vitro. Reprod Biol Endocrinol 2007;5:38.
114 Singh M, Zaino RJ, Filiaci VJ, Leslie KK: Relationship of estrogen and progesterone receptors to clinical outcome in metastatic endometrial carcinoma: a Gynecologic Oncology Group Study. Gynecol Oncol 2007; 106:325-333.

115 Ignatov A, Bischoff J, Schwarzenau C, Krebs T, Kuester D, Herrmann K, Costa SD, Roessner A, Semczuk A, Schneider-Stock R: P16 alterations increase the metastatic potential of endometrial carcinoma. Gynecol Oncol 2008;111:365-371.

116 Doll A, Gonzalez M, Abal M, Llaurado M, Rigau M, Colas E, Monge M, Xercavins J, Capella G, Diaz B, Gil-Moreno A, Alameda F, Reventos J: An orthotopic endometrial cancer mouse model demonstrates a role for RUNX1 in distant metastasis. Int J Cancer 2009;125:257-263.

117 Szewczuk W, Skomra D, Cybulski M, Prządka-Rabaniuk D, Filip A, Jóźwik M, Olcha P, Roessner A, Semczuk A: Allelic loss at TP53 in metastatic human endometrial carcinomas. Clin Exp Metastasis 2009; 26:789-796.

118 Gadducci A, Tana R, Cosio S, Fanucchi A, Genazzani AR: Molecular target therapies in endometrial cancer: from the basic research to the clinic. Gynecol Endocrinol 2008:24:239-249.

119 Fujita M, Enomoto T, Wada H, Inoue M, Okudaira Y, Shroyer KR: Application of clonal analysis. Differential diagnosis for synchronous primary ovarian and endometrial cancers and metastatic cancer. Am J Clin Pathol 1996;105:350-359.

120 Matias-Guiu X, Lagarda H, Catasus L, Bussaglia E, Gallardo A, Gras E, Prat J: Clonality analysis in synchronous or metachronous tumors of the female genital tract. Int J Gynecol Pathol 2002;21:205-211.

121 Prat J: Clonality analysis in synchronous tumors of the female genial tract. Hum Pathol 2002;33:383-385. 